\title{
Aprendizagem histórica em tempos de rupturas de paradigmas
}

\section{Historical Learning in Times of Paradigm Ruptures}

A Revista História Hoje aborda neste número a temática da aprendizagem histórica, por meio do Dossiê organizado por Marcella Albaine Farias da Costa e Marcus Leonardo Bomfim Martins. O Dossiê, intitulado Uma interpelação contínua ao ensino de História: a aprendizagem histórica em questão, estabelece pontos de convergência, conexões e tensões entre ensino e aprendizagem no contexto do ensino de História.

Os artigos presentes nesse Dossiê partem da aposta que consiste em condenar a separação radical de responsabilidades nas escolas que normalmente atribui ao docente a função exclusiva de "ensinar" e ao aluno a função de "aprender".

Ao discutir aprendizagem em uma área disciplinar específica, os proponentes desse Dossiê defendem o movimento dialético que mobiliza saberes e referenciais teórico-metodológicos tanto do campo educacional, como do disciplinar, no caso, da História. Nesse sentido, entendem que, de forma isolada, nem a ciência de referência, nem a didática geral são capazes de garantir as aprendizagens em sala de aula. Todavia, esta afirmação não é uma posição consensual entre aqueles que estudam a História escolar na contemporaneidade.

Em meio às lutas e litígios em torno dos polos da aprendizagem em História, termos como currículo, educação escolar, conteúdos, ensino, aprendizagem e formação cidadã são mobilizados em diversas direções pelas autorias dos artigos que ocupam as páginas da Revista.

Para os organizadores do Dossiê, as diferentes contribuições permitem ao/à leitor/a conhecer a diversidade de sentidos que a comunidade disciplinar da História atribui ao termo aprendizagem histórica; os fundamentos políticos e/ou epistemológicos/metodológicos que autorizam a emergência dos sentidos de aprendizagem histórica que povoam as aulas de História e pesquisas em 
ensino de História, e as implicações de tais sentidos nas práticas e relações entre sujeitos, e destes com os conhecimentos, experimentadas na aula de História na educação básica brasileira.

Em tempos de pandemia, distanciamento social e uso de tecnologias digitais de informação e comunicação, as questões que pautam o Dossiê são um instigante convite para se pensar qual é o futuro da escola, da disciplina de História e das formas de mediação e aprendizagens, considerando as diversas e contraditórias realidades socioeconômicas do Brasil.

Diante do duelo entre variados tipos de ensino - do presencial ao ensino à distância - emergem narrativas de estratégias, ou melhor, experiências de ensino e aprendizagens híbridas. Talvez seja uma terceira margem do rio da História escolar que não se pauta nos limites "fixos" das margens, mas nos percursos, movimentos, fluxos das águas que desenham esse caminho...

Desejamos a todos/as que aventurem-se pelas tramas e enredos da aprendizagem histórica em tempos de tantos desafios e quebra de paradigmas.

Renilson Rosa Ribeiro

Editor da RHHJ 